\title{
GROUNDWATER ANALYSIS OF ENVIRONMENTAL CARBON AND OTHER ISOTOPES FROM THE JAKARTA BASIN AQUIFER, INDONESIA
}

\author{
M A GEYH \\ Niedersächsisches Landesamt für Bodenforschung \\ and \\ BERND SÖFNER \\ Bundesanstalt für Geowissenschaften und Rohstoffe, \\ D-3000 Hannover, FRG
}

\begin{abstract}
Groundwater of the Jakarta Basin aquifer is heavily exploited for drinking water. As a result, the piezometric head has dropped dramatically. Extensive hydrogeologic and numeric model studies have been made to find a reliable basis for managing available groundwater resources. Environmental carbon $\left({ }^{14} \mathrm{C},{ }^{13} \mathrm{C}\right)$ and other isotope analyses $\left({ }^{18} \mathrm{O},{ }^{2} \mathrm{H},{ }^{3} \mathrm{H}\right)$ were made. Two sampling strategies were employed, which show that using well-defined and representative sampling sites, no matter how few, is the only way to obtain reliable geoscientific information. Large quantities of data from randomly distributed samples of uncertain origin is not recommended.
\end{abstract}

\section{INTRODUCTION}

The rapidly increasing demand for drinking and industrial water, especially in the commercial and industrial centers of the Third World, make it necessary to conduct comprehensive hydrogeologic studies on groundwater resources and management. Groundwater plays a dominant role in the drinking water supply because it is considered to be well protected from direct pollution. However, over-exploitation of the usually limited resources associated with drawdown of the groundwater table increases the danger of vertical entry of polluted water from a shallow aquifer into the underlying confined one.

Groundwater surveys involve the delineation of the aquifer system and an inventory of existing wells and construction details. Drilling records are frequently missing or incomplete due to inadequate administrative regulations. Often even the depths of wells and pumping rates cannot be verified. Under such conditions, any forecast of the response of an aquifer system to future increases in groundwater abstraction involves many uncertainties. One way to determine the origin of the pumped water is to analyze its chemical and environmental isotope content. Two procedures are used. Samples are collected from randomly distributed wells without construction documentation and the isotope data are treated statistically. The second method is to analyze a limited number of selected wells from which the construction details are available. We had the opportunity to compare the results obtained from both procedures in an Indonesian-German Technical Cooperation Program from 1983 to 1985 (Söfner, Hobler \& Schmidt, 1986).

\section{THE HYDROLOGY AND HYDROGEOLOGY OF JAKARTA}

The population of Jakarta was 7,500,000 in 1985 and is expected to increase to $>12,000,000$ by the year 2005 . The present water demand is ca $450,000,000 \mathrm{~m}^{3} / \mathrm{yr} ; 200,000,000 \mathrm{~m}^{3} / \mathrm{yr}$ are pumped from innumerable shallow 
wells and 50,000,000 $\mathrm{m}^{3} / \mathrm{yr}$ from deep wells, 50 times more than before 1945 . The pressure head of the deep groundwater system in the northern and central districts of Jakarta was 5-15m asl in 1900, and the wells were generally flowing. From 1900-1970, water levels dropped at a rate of $0.1-0.2 \mathrm{~m} / \mathrm{yr}$. Later, the rate locally increased to $>1 \mathrm{~m} / \mathrm{yr}$. In areas with intensive industrial development, the pressure head was between $10-30 \mathrm{~m}$ bsl in 1985 and even land subsidence became locally evident.

The aquifer system of Jakarta was delineated from archives data of the Geological Survey of Indonesia, recent results of geologic and geoelectric field studies, surveys of groundwater head and quality, and data from $>20$ recently constructed monitoring wells. The area finally selected for a detailed numeric model study extends to the Java Sea in the north, the Cisadane and Cikeas Rivers in the west and east, respectively, and the Depok area in the south. The base of the aquifer system consists of consolidated Miocene sediments, which crop out at the southern boundary. The basin fill consists of marine Pliocene and Quaternary fan and delta sediments $0->300 \mathrm{~m}$ thick. Djaeni et al (1986) believe that thin sandy aquifer layers only $1-5 \mathrm{~m}$ thick are intercalated in the predominantly silty, clayey sedimentary sequence and form a rather uniform aquifer system, which for the region as a whole can be treated hydraulically as a rather homogeneous and isotropic medium. An older idea (Sukardi, 1982) divides the basin fill into three confined aquifers regionally well separated by continuous aquicludes.

According to Djaeni et al (1986), the horizontal hydraulic conductivity is $0.1-40 \mathrm{~m} / \mathrm{d}$ and the vertical hydraulic conductivity is $100-5000$-fold smaller, hampering the replenishment of the deeper aquifer system from which groundwater is pumped. Only the shallow unconfined aquifer is fully replenished during the rainy season. Deep groundwater generally moves from the recharge area in the south (precipitation $>2900 \mathrm{~mm} / \mathrm{yr}$ ) to the discharge area of the coastal plain (precipitation ca $1700 \mathrm{~mm} / \mathrm{yr}$ ). However, the horizontal inflow across the hinge line, estimated to be $15,000,000 \mathrm{~m}^{3} / \mathrm{yr}$, does not counterbalance the pumping rate of ca $50,000,000 \mathrm{~m}^{3} / \mathrm{yr}$ (Soefner, Hobler \& Hobler, 1986).

\section{ENVIRONMENTAL ISOTOPE STUDY OF RANDOMLY DISTRIBUTED WELLS}

Wandowo, Manurung \& Zainal (1985) analyzed the environmental isotopes of samples collected from 130 randomly distributed wells in the Jakarta city district. Information on construction details was generally uncertain (Wandowo, pers commun). Results of ${ }^{14} \mathrm{C}$ measurements and corresponding $\delta^{13} \mathrm{C}$ values for 75 samples, ${ }^{3} \mathrm{H}$ dates for 111 samples, as well as $\delta^{2} \mathrm{H}$ and $\delta^{18} \mathrm{O}$ values for 91 samples, showed that several ${ }^{14} \mathrm{C}$ and ${ }^{3} \mathrm{H}$ values are clearly below the detection limits.

The conventional ${ }^{14} \mathrm{C}$ ages plotted $v s$ the performed sampling depth are shown in Figure 1. Wandowo, Manurung and Zainal (1985) observed a trend of increasing ${ }^{14} \mathrm{C}$ water ages with depth. From these dates we calculated mean values for ${ }^{14} \mathrm{C}$ ages, $\delta^{18} \mathrm{O}$, and $\delta^{2} \mathrm{H}$ for the samples from the wells grouped in three depth ranges $(0-60 \mathrm{~m}, 60-150 \mathrm{~m}$, and $150-250 \mathrm{~m})$. Only a weak depth trend of the mean ${ }^{14} \mathrm{C}$ ages is visible and was interpreted as confirmation of the presence of a confined three-aquifer system. The decreasing 


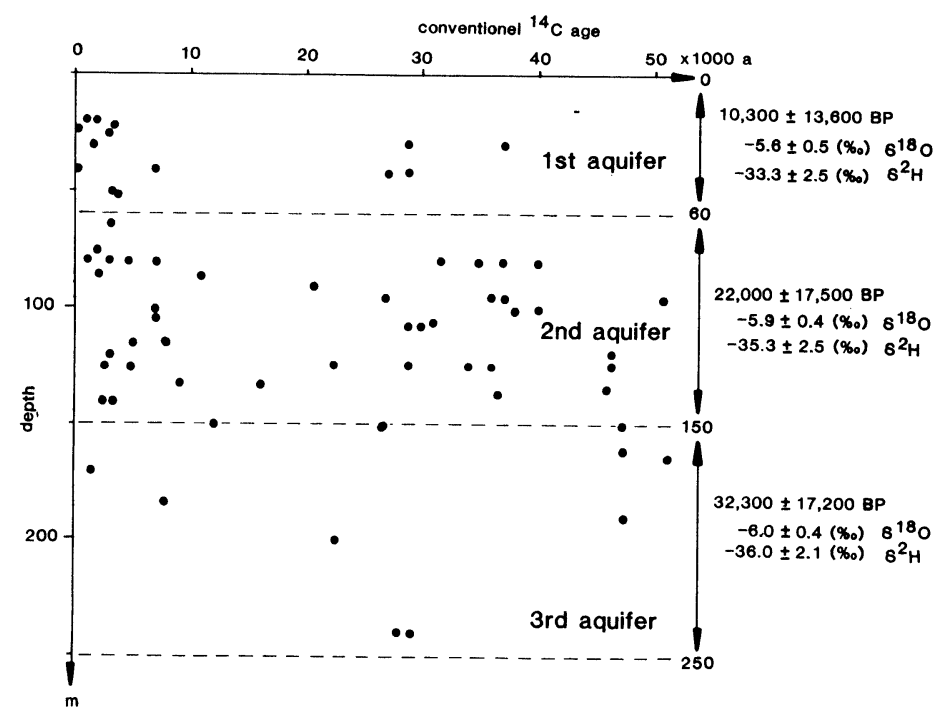

Fig 1. Conventional ${ }^{14} \mathrm{C}$ ages of randomly distributed groundwater samples from the Jakarta City district $v s$ assumed sampling depth and calculated mean values for conventional ${ }^{14} \mathrm{C}$ ages, $\delta^{18} \mathrm{O}$, and $\delta^{2} \mathrm{H}$ for different ranges of assumed well depth (after Wandowo, Manurung \& Zainal, 1985)

$\delta^{18} \mathrm{O}$ and $\delta^{2} \mathrm{H}$ values with increasing depth may reflect the altitude effect as the deep groundwater is recharged in areas with altitudes above $200 \mathrm{~m}$ in the south while the shallow groundwater is replenished locally at near sea level. All groundwater ages are rather high and increase from south to north.

\section{ENVIRONMENTAL ISOTOPE STUDY OF WELL-DEFINED} REPRESENTATIVE WELLS

In 1985, we did environmental isotope and hydrochemical analyses on 21 samples from selected wells in the Jakarta city district for which construction details were available. The isotope results and a selection of the hydrochemical data are compiled in Table 1. The complete data are in Geyh, Hobler and Söfner (1986). The conventional ${ }^{14} \mathrm{C}$ ages and $\delta^{13} \mathrm{C}$ values are represented in Figure 2.

Measurable tritium was found only in a sample from the recharge area in the south. The general trend of increasing and quite large ${ }^{14} \mathrm{C}$ water ages from south to north was confirmed. Hence, the bulk of groundwater in the aquifer system was recharged a long time ago. In disagreement with the statement derived from the statistical evaluation of the ${ }^{14} \mathrm{C}$ ages (Wandowo, Manurung \& Zainal, 1985), there is no definite relationship between ${ }^{14} \mathrm{C}$ age and sampling depth. The ${ }^{14} \mathrm{C}$ ages of the deepest groundwater may be even lower than those of the shallower groundwater.

A rough estimate of $1 \mathrm{~m} / \mathrm{yr}$ may be made for the tracer velocity from the ${ }^{14} \mathrm{C}$ data. A value of $1.6 \mathrm{~m} / \mathrm{yr}$ was obtained from the Darcy law using a mean gradient of the groundwater table of $1 / 1500$ and a mean conductivity of 1.5 $\times 10^{-5} \mathrm{~m} / \mathrm{s}$. Total porosity was assumed to be $20 \%$. Considering the uncertainties in estimating regionally valid hydraulic parameters, as well as in ${ }^{14} \mathrm{C}$ groundwater dates, agreement is excellent. 


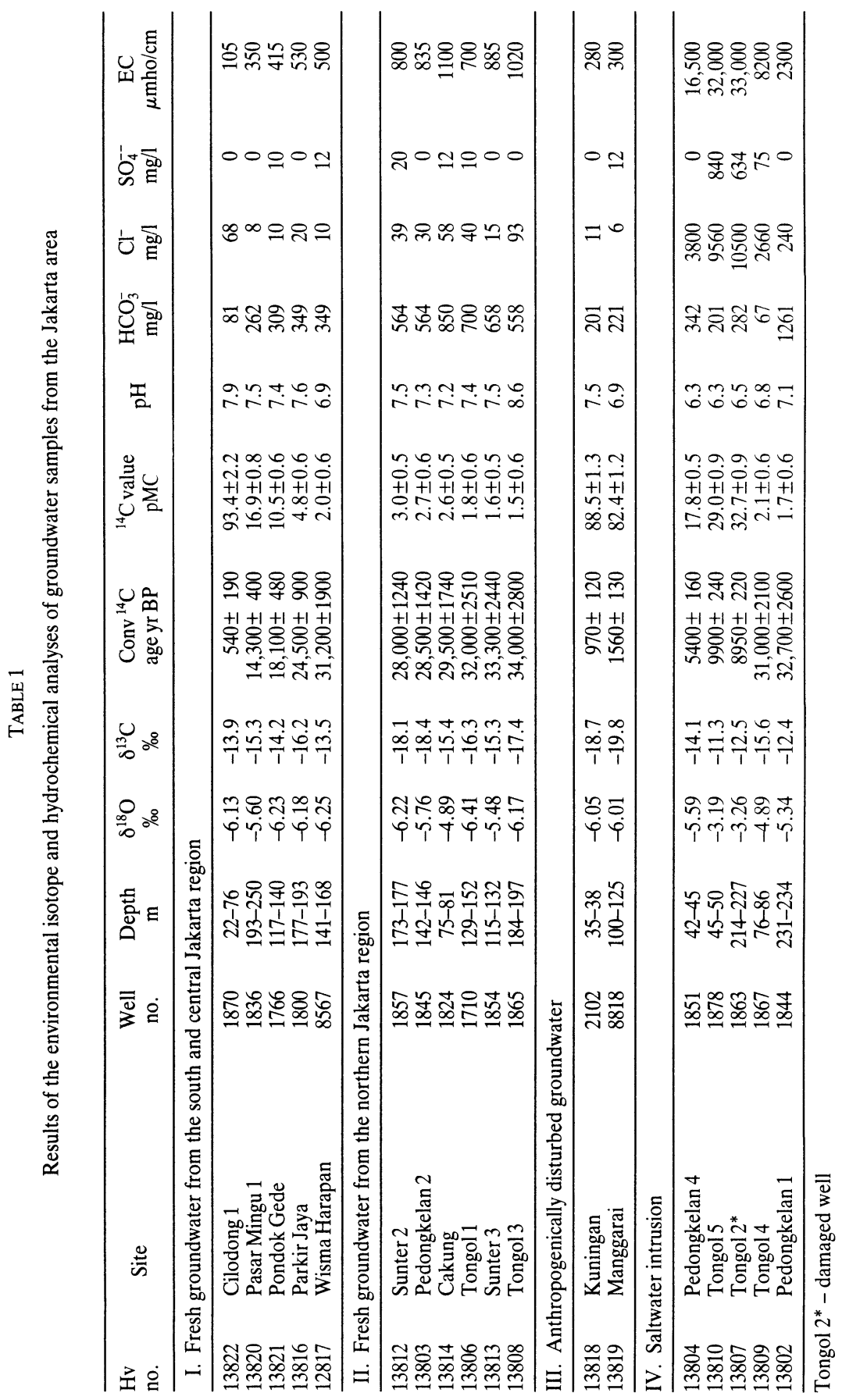




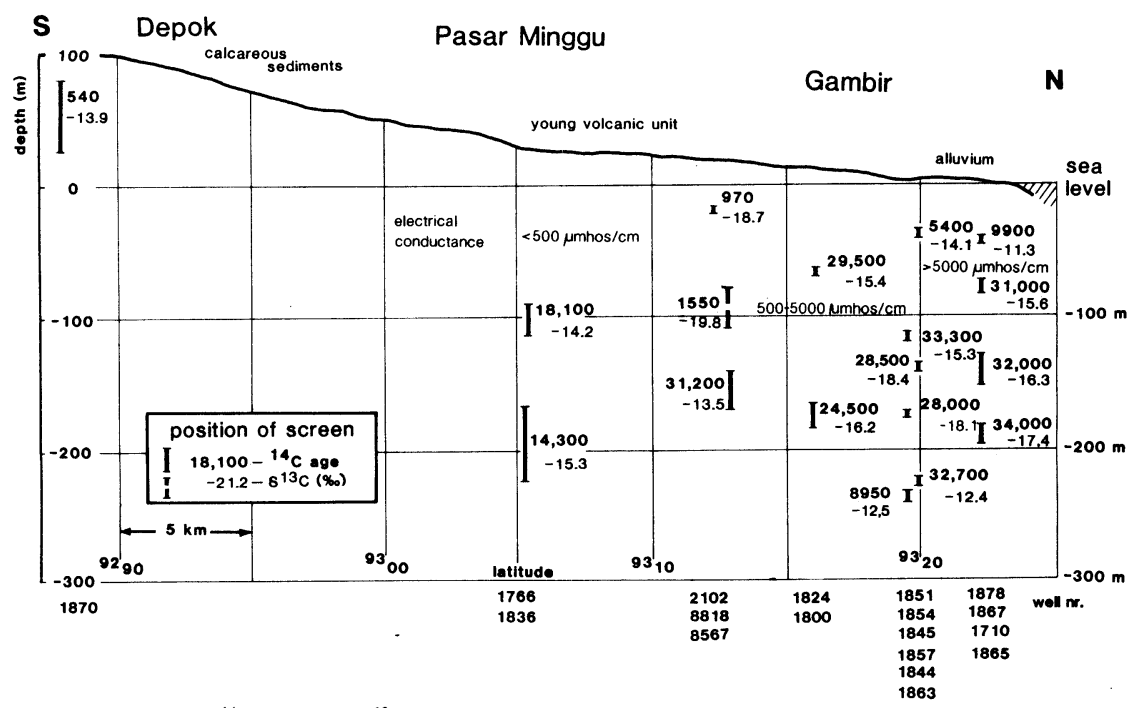

Fig 2. Conventional ${ }^{14} \mathrm{C}$ ages and $\delta^{13} \mathrm{C}$ values of representative groundwater samples from the Jakarta City District $v s$ sampling depth (after Wandowo, Manurung \& Zainal, 1985)

There are three new results: 1) rather low ${ }^{14} \mathrm{C}$ water ages were found in southern and central Jakarta; 2) according to the $\delta^{18} \mathrm{O}$ values and the chloride content, ocean water is the origin of the high mineral content of the upper part of the aquifer system of northern Jakarta; 3) most of the $\delta^{13} \mathrm{Cl}$ $\mathrm{HCO}_{3}^{-}$values cluster in three groups.

The $\delta^{13} \mathrm{C}$ values were plotted $v s$ the bicarbonate concentration (Fig 3 ). Freshwater samples from southern and central areas of the study, which have

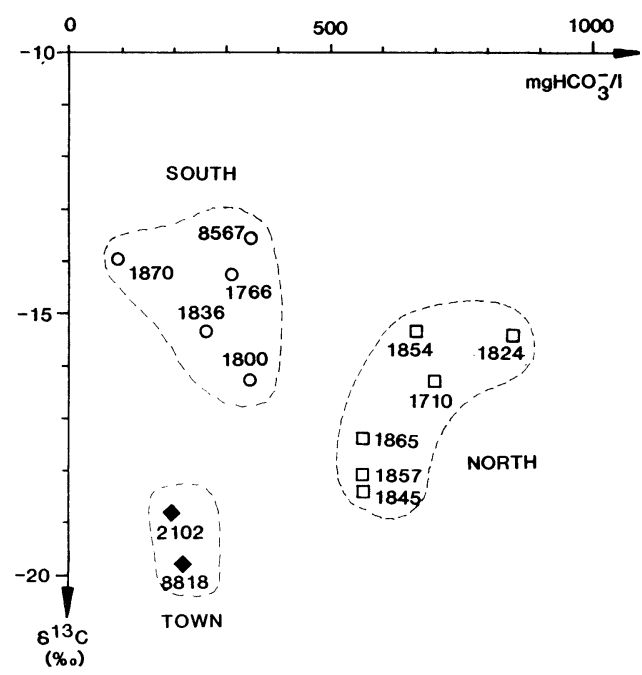

Fig 3. $\delta^{13} \mathrm{C}$ values for the DIC of groundwater samples from the Jakarta district $v s$ bicarbonate concentration 
conventional ${ }^{14} \mathrm{C}$ ages of up to $30,000 \mathrm{yr}$, form one group. The bicarbonate content increases rapidly from $80 \mathrm{mg} / \mathrm{l}$ in the recharge area to a rather constant value of ca $300 \mathrm{mg} / \mathrm{l}$ for the groundwater older than $10,000 \mathrm{yr}$. Hence, any correction for the corresponding ${ }^{14} \mathrm{C}$ ages concerning the initial ${ }^{14} \mathrm{C}$ content would only shift all the ${ }^{14} \mathrm{C}$ water ages in one direction but would not change the relative ages.

The second group of $\delta^{13} \mathrm{C} / \mathrm{HCO}_{3}^{-}$values is for water samples with bicarbonate concentrations of $550-800 \mathrm{mg} / \mathrm{l}$ and ${ }^{14} \mathrm{C}$ ages exceeding $28,000 \mathrm{yr}$. The corresponding samples are from the northern part of the study area. The bicarbonate concentration tends to decrease with increasing depth. Again, age correction would not change the picture. Due to the different bicarbonate contents of the two groups of groundwater there may be an age bias between the first and second one of $5000 \mathrm{yr}$.

These observations might be explained by changes in the paleohydrogeological situation during the last $30,000 \mathrm{yr}$. At the beginning of this period, the sea level was a maximum of ca $100 \mathrm{~m}$ lower than today and the surface may have consisted of both calcareous and volcanic sediments. In recharge areas formed by calcareous sediments, groundwater with rather high bicarbonate values was recharged compared to groundwater from volcanic areas. After that, the sea level rose and volcanic sediments covered most of the calcareous sediments. Hence, the old groundwater with high $\delta^{13} \mathrm{C}$ and bicarbonate values might be a relic of former times.

The groundwater ages agree better with the results of the numeric model (Djaeni et al, 1986) than with that of the old hydrogeological concept. A final decision whether a confined three-aquifer system exists is not possible with so little data. This is mainly due to the fact that we are most probably dealing with long-term processes in which groundwater seeped through aquitards for thousands of years. This may also have changed the ${ }^{14} \mathrm{C}$ values of the groundwater by mixing groundwater of different ages (Geyh et al, 1984).

The third cluster of $\delta^{13} \mathrm{C} / \mathrm{HCO}_{3}^{-}$values (Fig 3) represents samples from a part of the natural groundwater system that may be disturbed due to overexploitation. Groundwater with low ${ }^{14} \mathrm{C}$ ages from the shallow aquifer appears to have already entered the deeper part of the system. If this is true, repeated ${ }^{14} \mathrm{C}$ analysis may help to monitor mining of fossil groundwater.

A fourth group of groundwater samples showed elevated chloride contents. This is explained by encroachment of seawater into the aquifer, mainly due to the drop in hydraulic pressure head. However, the high age of well no. 1867 indicates that mixing of seawater and freshwater occurred, at least locally, in the past. The plot of chloride $v s \delta^{18} \mathrm{O}$ values shows a mixing line between seawater and freshwater (Fig 4). 


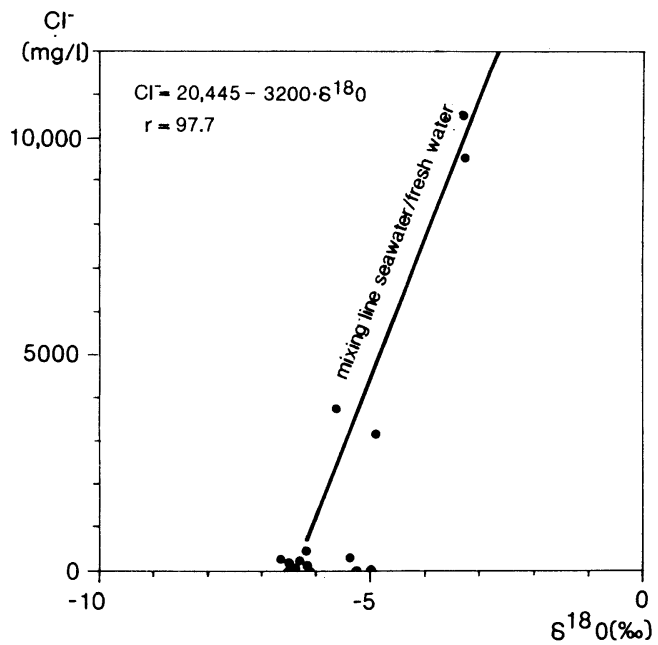

Fig 4. $\delta^{18} \mathrm{O}$ and chloride mixing line for water samples from the Jakarta region

\section{CONCLUSION}

A comparison of the results from a study conducted on samples from randomly distributed wells for which construction details were not available and one on samples from a selection of representative wells in the Jakarta city district for which the construction details were known proved that only the data from the latter study yield hydrogeologically reliable information. For such studies, however, a detailed hydrogeological survey made prior to the sampling to select wells with well-know construction details (filter depth, coordinates, etc) is indispensable. The hydrological isotope study is then even less expensive and less time consuming than the analysis of randomly collected samples.

\section{REFERENCES}

Djaeni, A, Hobler, M, Schmidt, G, Soekardi, P and Söfner, B, 1986, Hydrological investigations in the Greater Jakarta Area of Indonesia: Salt water intrusion meeting, Proc: Delft, The Netherlands, $\mathrm{p}$ 165-176.

Geyh, M A, Backhaus, G, Andres, G, Rudolph, J and Rath, H K, 1984, Isotope study on the Keuper sandstone aquifer with a leaky cover layer: IAEA, Vienna, Isotope Hydrology $1983, \mathrm{p} 499-513$.

Geyh, M A, Hobler, M and Söfner, B, 1986, Isotope investigations on groundwater samples from the confined aquifer system: German Hydrogeological Advisory Group in Indonesia - CTA 40, Hannover, (HAG), working paper, v 124, p 1-28.

Soefner, B, Hobler, M and Schmidt, G, 1986, Jakarta groundwater study - final report: German Hydrogeological Advisory Group (CTA 40), Directorate of Environmental Geol, Bandung; Fed Inst Geosci Natural Resources, Hannover, working paper, v 117, p 1-71.

Sukardi, R, 1982, Aspek Geologi Terhadap Perkemban-gan Pantai dan Tata Airtanah Daerah Jakarta: Sarjana thesis, Jurusan Geol, Fakultas Ilmu Pasti dan Pengetahuan Alam, Univ Padjadjaran, Bandung, p 1-139.

Wandowo, I, Manurung, S and Zainal, A, 1985, Groundwater studies in Jakarta and vicinity: Jakarta Centre Application of Isotopes \& Radiation, Natl Atomic Energy Agency, p 1-34. 